\title{
EFFECTS OF PHENOLOGICAL STAGE ON FORAGE QUALITY OF HALOPHYTE SPECIES SALSOLA ARBUSCULA PALL. IN THE CENTRAL DESERT OF IRAN
}

\author{
ABTAHI, M. ${ }^{* 1}-$ ZANDI ESFAHAN, E. $^{2}$ \\ ${ }^{1}$ Research Division of Natural Resources, Esfahan Agricultural and Natural Resources \\ Research and Education Center, Agricultural Research, Education and Extension Organization \\ (AREEO), Esfahan, Iran \\ ${ }^{2}$ Rangeland Research Division, Research Institute of Forests and Rangelands, Agricultural \\ Research, Education and Extension Organization (AREEO), Tehran, Iran \\ *Corresponding author \\ e-mail:m-abtahi@areeo.ac.ir; phone:00989131634861; fax:00983155574600 \\ (Received $3^{\text {rd }}$ Oct 2016; accepted $3^{\text {rd }}$ Mar 2017)
}

\begin{abstract}
Information on forage quality of halophytes in 3 phenological stages could help range managers to determine suitable grazing time to achieve higher animal performance in saline rangelands. Salsola arbuscula Pall. a perennial plant species and resistant to drought and salinity, is distributed in the winter rangelands of the deserts. This plant with Astragalus squarrosus forms a vegetation type in the desert region of Kashan, located in the central region of Iran. To study the forage quality of Salsola arbuscula at three growth stages (vegetative, flowering and seeding), the branches of 10 specimens were randomly sampled with three replications. Then, the samples were dried and milled. Vegetative growth stage is from mid-March to mid-May, flowering is from mid-May to late June and seeding stage starts from early July. Eight forage quality traits including DMD (Dry matter digestibility), WSC (Watersoluble carbohydrate), CP (Crude protein), CF (Crude fiber), ADF (Acid detergent fiber), NDF (Neutral detergent fiber), Ash and ME (Metabolizable energy) were measured. Data were analyzed in a completely randomized design analysis of variance and means were compared by Duncan's test at the 5\% level. The results indicated that the forage quality of Salsola arbuscula was affected by phenological stages. The highest percentage of $\mathrm{CP}$ and WSC was estimated in the vegetative stage, CF and NDF at flowering stage and DMD, ash and ME in the seeding stage. Due to the high percentage of CP and WSC, the vegetative stage was determined as the best time for forage utilization of Salsola arbuscula.
\end{abstract}

Keywords: dry matter digestibility; flowering; Kashan; protein; seed

\section{Introduction}

Saline and alkaline soils cover $204800 \mathrm{~km}^{2}$ of Iran's area (Aghakhani and Ghorbanli, 1993). Regarding the extension of saline and alkaline soils and the importance of halophytes from the various aspects such as medicinal, industrial and forage, identifying and evaluation the changes of their nutritional value at different growth stages in different habitats can be helpful in planning livestock feed supply in the current critical circumstances (Amiri and Rasouli, 2011). According to CRISP classification, a saline soil has an EC equal or greater than 4 Ds/m (El-Bassiouny and bekheta, 2007). High salinity causes changes in the leaf thickness, cell size, the number of stomata and epidermal cells (Cavusoglu et al., 2007). Increased salinity stress causes many anatomical changes such as an increase in the leaf thickness, number of epidermal cells and stomata (Kilic et al., 2007).

Halophytes and other salt-resistant plants can provide suitable and reasonable alternatives for forage supply in developing countries (Squires and Ayoub, 1994). These 
plants grow naturally or planted in lands affected by salinity such as saline semi-arid areas, mangrove wetlands, swamps, degraded soils and coasts, and have the advantage to tolerate high levels of salinity in saline lands (Zahran, 1993). Many of plants growing in saline soils can produce high to moderate usable biomass (Zahran, 1986; Le Houérou, 1994; El- Shaer et al., 2005). Therefore, vegetative production of halophytes and other salt tolerant species can be considered a significant potential especially as a source of livestock feed (Anon, 2009). Halophytes and salt tolerant plants could be a suitable livestock feed source in arid and semi-arid areas, through encouraging farmers to grow and produce plants resistant to salinity in the margins of saline lands (Le Houérou, 1993; Glenn et al., 1999; El Shaer et al., 2005).

Chenopodiaceae is an important family of the vegetation in arid and saline areas worldwide. The genus Salsola is one of the largest genera of the family Chenopodiaceae, playing an important role in rehabilitation of arid rangelands and saline areas. The advantage of this genus than other genera is that it is a forage plant in addition to be a woody one and it has good seed productivity and high forage production (Bakhshi Khaniki, 2006). Different species of this genus are distributed in most parts of Iran except the northern and western forested areas and can be seen more in saline and desert areas (Mozaffarian, 1996).

The forage quality of halophytes and salt tolerant species depends on a combination of climatic, soil and plants factors. These species are significantly different in terms of nutritional value and forage quality due to changes in environmental conditions and the management type (Abd El-Rahman, 1996; Le Houérou, 1994; Gihad and El Shaer, 1994; Abd El Aziz, 1982). Climatic factors such as temperature, humidity, rainfall and light intensity play an important role in forage quality and nutritional value of plants, so that affect the intake, photosynthesis and metabolism of plants. Higher forage palatability, digestibility and adequate nutritional value can significantly increase forage quality. As mentioned earlier, biomass production, palatability and nutritional value of halophytes differ from region to region and from season to season and this change depends on many environmental factors. In addition, the nutritional value of halophytes and salt tolerant plants is very different between the genera and even between various species of the same genus; the forage quality considerably varies at different phenological stages and different places (Stoddart et al., 1975). According to some reports, species type, leaf to stem ratio, growth stage, soil and climate factors, and pests and diseases are the factors affecting the forage quality (Arzani et al., 2001; Harrocks and Valentine, 1999). Among the above factors, phenological stages are considered as the most important factors influencing the quality of forage for grazing on rangeland species (Fahey, 1994). There are large differences between species and genera of plants, especially in terms of chemical composition and dry matter and organic matter digestibility (Le Houérou, 1994). Crude protein (CP) is one of the main factors in forage quality. Absorbable protein in the rumen can be increased by reducing the protein degradation process in the rumen. Increasing of soluble carbohydrates to supply the energy required by microorganisms is essential for more protein absorption by livestock (Hoffman et al., 2003). Livestock performance depends on the absorption of digestible and metabolizable nutrients. A small change in digestibility can lead to a relatively large change in optional absorption (Walters, 1984). The ripening stage and plant age have a greater impact on forage quality compared to other environmental factors. The maximum reduction in the forage digestibility is at the reproductive growth stage (Buxton et al., 1996). The ADF (Acid detergent fiber) percentage is increased with the 
growth of stem height, so that cellulose and other structural carbohydrates are accumulated in the cell wall at the maturity stage. This process is called lignification. Leaf to stem ratio is one of the factors, affecting the forage quality significantly. With the gradual growth of the plant, leaf to stem ratio will change. With increasing of CF (Crude fiber), the digestibility percentage and energy values are reduced and thus the quality of forage is decreased (Hoffman et al., 2003). The majority of halophytes are of nutritious in wet seasons to meet the needs of livestock. However, the nutritional value of these species is low in the summer and autumn (dry season), and it is necessary to use other food sources, particularly in terms of energy as a supplement (Atiq-ur-Rehman, 2002). Livestock grazing of halophytes species cultivated in saline soils of Egypt has been reported as a potential, so that in addition to maintaining health sheep, goats and camels could graze for two months with no signs of toxicity (Zahran et al., 1999; El Shaer and Zahran, 2002).

The effects of phenological stages on soluble carbohydrates of two species Salsola arbuscula and Salsola richteri studied in Sabzevar (Iran) saline rangelands (Dianati Tilaki et al., 2011). The forage quality of 9 rangeland species investigated in Meymeh (Iran) (Arzani et al., 2014). The forage quality of 5 important species of perennial grasses studied at three phenological stages in summer rangelands of Gorgan (Iran), and concluded that forage quality of all five species were different (Hosseini et al., 2014).

The aim of this study was to study the forage quality of Salsola arbuscula at 3 phenological stages in saline areas around Kashan Salt Lake of Iran.

\section{Materials and methods}

According to the literature review and existing vegetation maps as well as field visits Salsola arbuscula forms a vegetation type in the desert areas of Kashan located on the longitude of 514611 and latitude of 340424 at a height of 900 meters (Fig.1). The average annual rainfall and temperature is $137 \mathrm{~mm}$ and $18.9^{\circ} \mathrm{C}$. The climate of this area is hyper arid based on the De Martonne method (Aridity index=4.7) (Abtahi and Darvish, 2016). The soil of the study vegetation type is gypsum and light (Table 1). Calligonum polygonoides, Haloxylon ammodendron, Astragalus squarrosus Bunge, Salsola tomentosa, Seidlitzia rosmarinus, Cornulaca leucacanth are the associated species in this vegetation type. The vegetative growth stage in this area is from mid-March to mid-May, flowering stage is from mid-May to late June and the seeding stage is early July (Fig. 2).

Table 1. Soil Characteristics of the Salsola arbuscula habitat

\begin{tabular}{|c|c|c|c|c|c|c|c|c|c|c|c|c|c|c|}
\hline Sample & $\begin{array}{l}\text { Depth } \\
(\mathrm{Cm})\end{array}$ & $\begin{array}{c}\text { Gypsum } \\
(\%)\end{array}$ & $\begin{array}{c}\mathrm{Ec} \\
(\mathrm{Ds} / \mathrm{m})\end{array}$ & $\mathrm{pH}$ & $\begin{array}{c}\mathrm{N} \\
(\%)\end{array}$ & $\begin{array}{c}\mathrm{C} \\
(\%)\end{array}$ & $\begin{array}{l}\text { TNV } \\
(\%)\end{array}$ & $\underset{(\mathrm{mg} / \mathrm{kg})}{\mathrm{P}}$ & $\underset{(\mathrm{mg} / \mathrm{kg})}{\mathrm{K}}$ & $\underset{(\mathrm{mg} / \mathrm{kg})}{\mathrm{Cu}}$ & $\underset{(\mathrm{mg} / \mathrm{kg})}{\mathrm{Zn}}$ & $\underset{(\mathrm{mg} / \mathrm{kg})}{\mathrm{Mn}}$ & $\underset{(\mathrm{mg} / \mathrm{kg})}{\mathrm{Fe}}$ & Texture \\
\hline \multirow{2}{*}{1} & $0-10$ & 30.1 & 8.6 & 7.7 & 0.01 & 0.05 & 64 & 3.8 & 80 & 0.74 & 0.44 & 0.86 & 1.9 & Sandy \\
\hline & $\begin{array}{c}10- \\
50\end{array}$ & 25.8 & 7.02 & 7.6 & 0.01 & 0.05 & 66 & 2.6 & 75 & 0.44 & 0.22 & 0.7 & 1.06 & Sandy \\
\hline \multirow{2}{*}{2} & $0-10$ & 28.29 & 8.7 & 7.9 & 0.02 & 0.03 & 67 & 4.1 & 87 & 0.69 & 0.42 & 0.95 & 1.6 & Sandy \\
\hline & $\begin{array}{c}10- \\
50 \\
\end{array}$ & 26.5 & 6.9 & 7.5 & 0.01 & 0.04 & 63 & 2.5 & 79 & 0.51 & 0.28 & 0.8 & 0.99 & Sandy \\
\hline \multirow{2}{*}{3} & $0-10$ & 31.2 & 8.9 & 7.8 & 0.01 & 0.05 & 68 & 3.7 & 79 & 0.78 & 0.45 & 0.82 & 1.85 & Sandy \\
\hline & $\begin{array}{c}10- \\
50\end{array}$ & 28.5 & 7.1 & 7.8 & 0.01 & 0.04 & 69 & 2.6 & 73 & 0.34 & 0.21 & 0.6 & 1.3 & Sandy \\
\hline
\end{tabular}




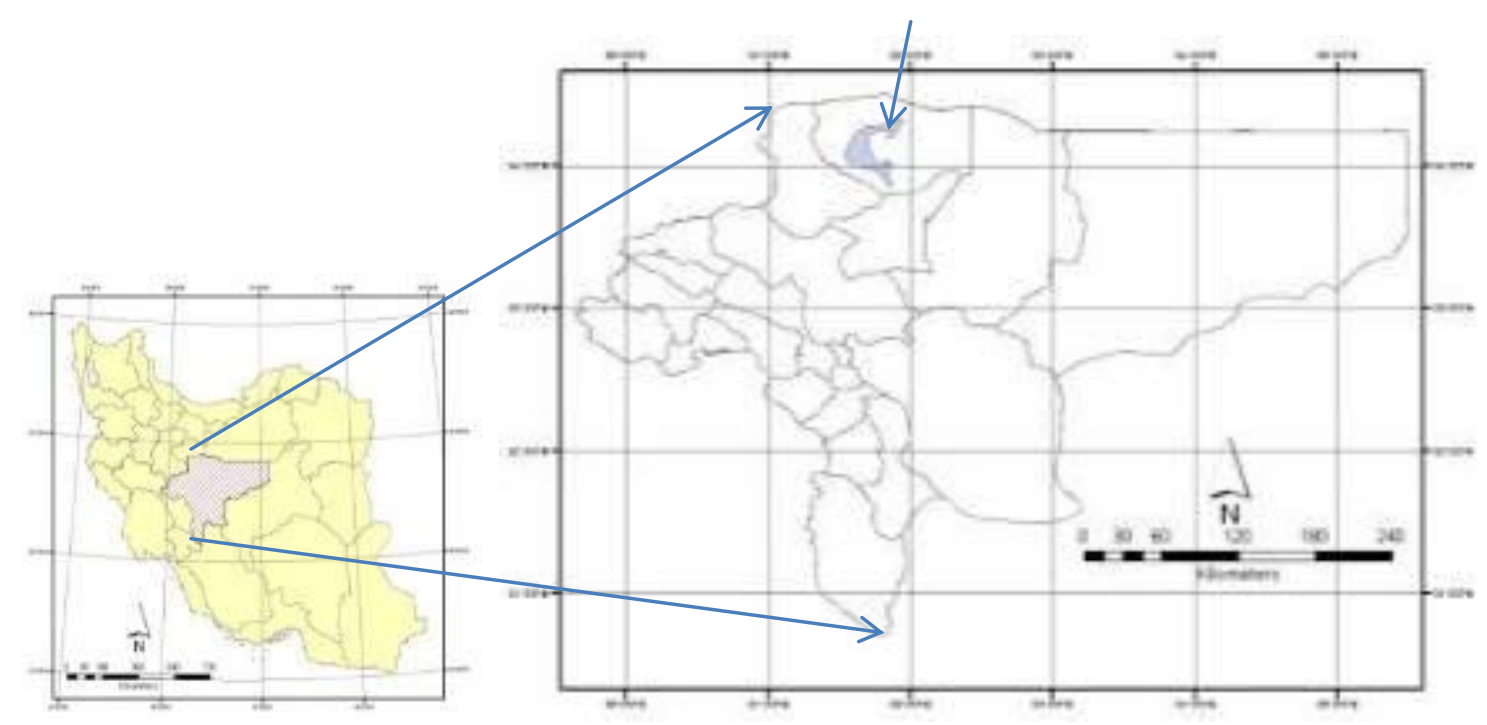

Figure 1. Location of Salsola arbuscula in the desert areas of Kashan

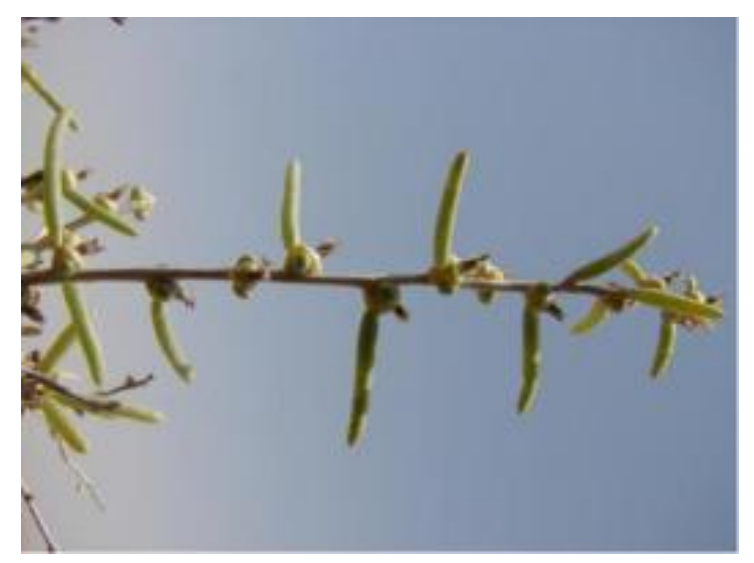

Flowering stage

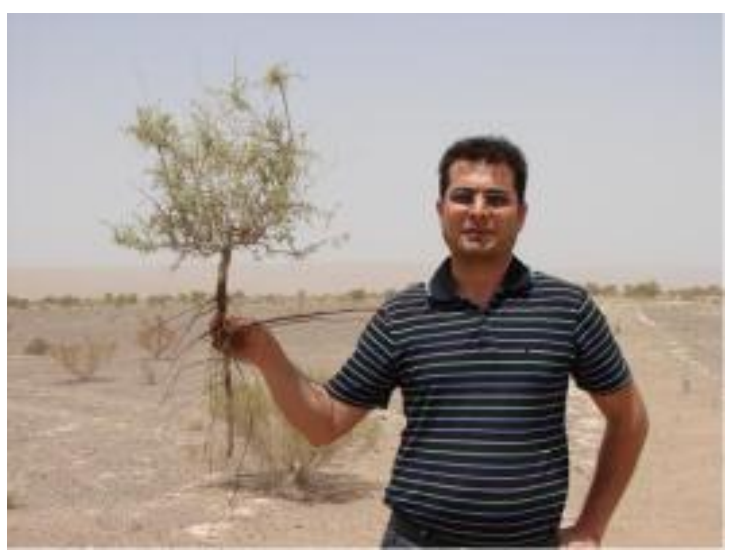

Root system

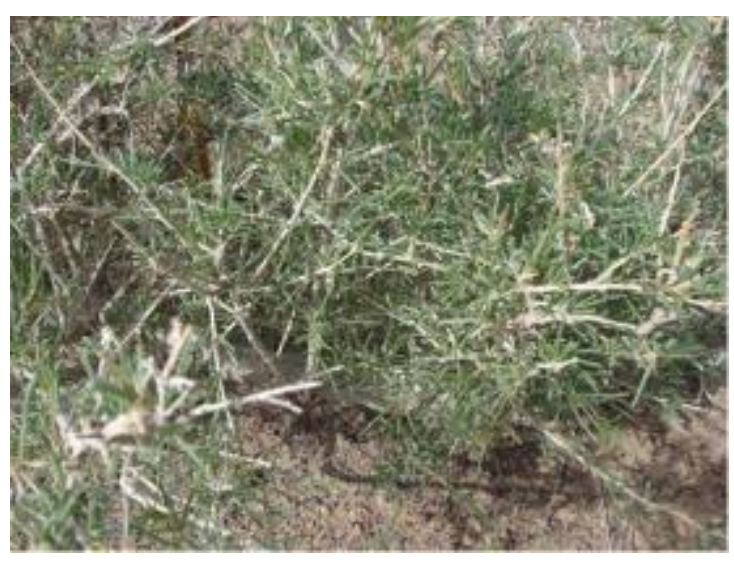

Vegetative stage

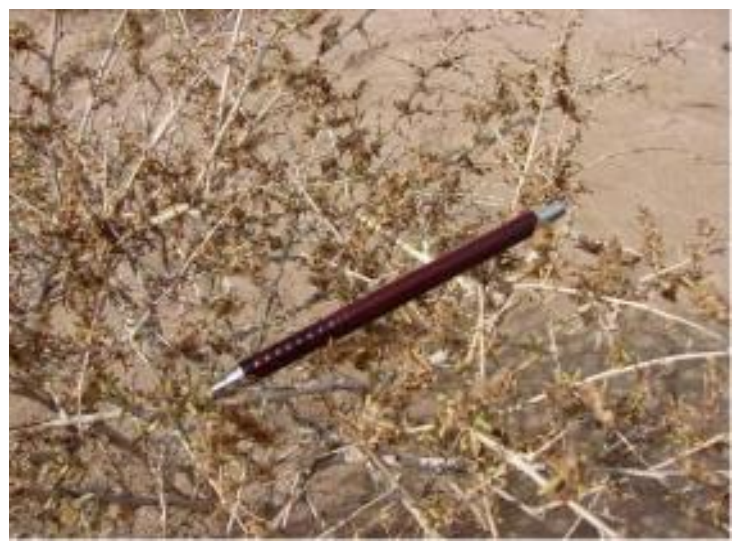

Seeding stage 


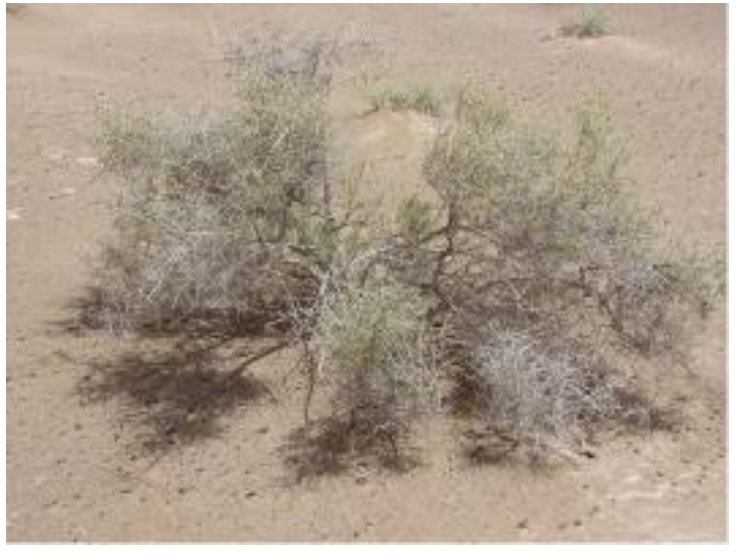

Plant form of Salsola arbuscula

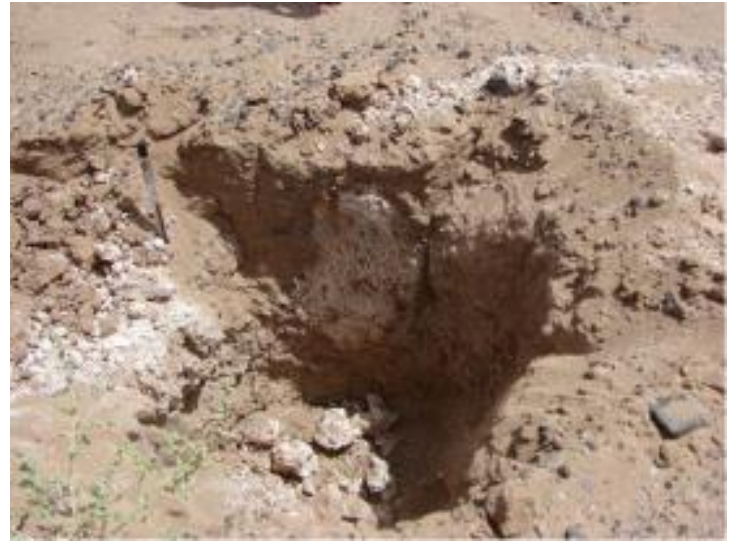

Soil profile

Figure 2. Plant form of Salsola arbuscula in 3 phenological stages

This study was conducted as a completely randomized design with three replications. In addition in order to compare the averages, Duncan method was used at 5\% level. All statistical analysis was done using software SPSS 17. In order to evaluate the forage quality (nutritional value), the sampling from the areal organs was performed at each stage of growth, vegetative, flowering and seeding stages at the dates of 2014/24/01, 2013/22/03 and 2013/19/08, respectively. In each phenological stage, 10 specimens were sampled with three replications. The Samples were dried in the open air for two weeks and then were placed in the oven at $70^{\circ} \mathrm{C}$ for 24 hours. Each sample powder was prepared using a mill and passing through a sieve of $1 \mathrm{~mm}$. Nine samples of three replications at three phenological stages were sent to the Iranian Research Institute of Forests and Rangelands for qualitative analysis. Eight forage quality traits were determined using NIR device (Near Infrared Spectroscopy) model INFRAMATIC8620 (Jafari et al., 2003, and Association of Official Analytical Chemists (AOAC), 1990) as follows: DMD (Dry matter digestibility), WSC (water-soluble carbohydrate), CP (crude protein), CF (crude fiber), ADF (acid detergent fiber), NDF (neutral detergent fiber), Ash and ME (metabolizable energy). The ME content was estimated by equation (1).

$$
\mathrm{ME}(\mathrm{Mj} / \mathrm{kg})=0.17 \mathrm{DMD}-2
$$

The forage yield of $S$. arbuscula was determined using cutting and weighing method for 30 individuals at the vegetative and beginning flowering stages.

\section{Results}

The measurement of $S$. arbuscula forage productivity showed that each plant produces $154 \mathrm{~g}$ dry matter. Taking into account 1100 plants per hectare in studied rangeland conditions, exploitable amount of dry matter per unit area (hectare) are estimated at $169.4 \mathrm{~kg}$. Given an area of 300 hectares of this plant type in the region, $50820 \mathrm{~kg}$ of dry matter is expected for the whole area of study. It should be noted that the forage yield of associated species is not considered in this review; therefore, the forage yield potential would be much more than the estimated amount due to the variety 
and palatability of most of them. The results of the qualitative analysis for nine samples, consisting of eight traits, are presented in Table 2.

Table 2. Result of forage quality analysis for S. arbuscula

\begin{tabular}{|c|c|c|c|c|c|c|c|c|}
\hline Phenology & $\mathrm{DMD}(\%)$ & $\mathrm{CP}(\%)$ & $\mathrm{WSC}(\%)$ & $\mathrm{CF}(\%)$ & $\mathrm{ADF}(\%)$ & $\mathrm{NDF}(\%)$ & $\mathrm{ASH}(\%)$ & $\mathrm{ME}(\mathrm{Mj} / \mathrm{kg})$ \\
\hline \multirow{4}{*}{$\begin{array}{c}\text { Vegetative } \\
\text { stage }\end{array}$} & 53.67 & 14.29 & 22.52 & 34.80 & 38.92 & 19.21 & 4.36 & 7.12 \\
\cline { 2 - 9 } & 50.27 & 14.08 & 21.79 & 35.23 & 42.22 & 25.00 & 4.14 & 6.55 \\
\cline { 2 - 9 } & 50.07 & 15.43 & 22.40 & 34.49 & 42.60 & 22.25 & 4.82 & 6.62 \\
\hline \multirow{4}{*}{$\begin{array}{c}\text { Flowering } \\
\text { stage }\end{array}$} & 47.99 & 9.92 & 16.07 & 42.71 & 45.00 & 41.56 & 5.57 & 6.16 \\
\cline { 2 - 9 } & 45.70 & 8.91 & 15.87 & 43.07 & 46.90 & 41.28 & 5.65 & 5.77 \\
\hline \multirow{4}{*}{\begin{tabular}{c} 
Seeding stage \\
\cline { 2 - 9 }
\end{tabular}} & 54.01 & 9.63 & 15.34 & 43.58 & 48.91 & 44.26 & 5.37 & 5.50 \\
\cline { 2 - 9 } & 58.61 & 10.29 & 19.90 & 41.83 & 38.00 & 30.54 & 5.39 & 7.96 \\
\hline
\end{tabular}

The analysis of variance for the qualitative traits of $S$. arbuscula is presented in Table 3. As can be seen, the forage qualitative traits varied significantly at phenological stages at $1 \%$ level. Table 4 shows the comparison of the means for forage qualitative traits of S. arbuscula. Accordingly, the highest CP and WSC content was observed at vegetative growth stage, CF, $\mathrm{ADF}, \mathrm{NDF}$ and ash at the flowering stage; and DMD, ash and ME at the seeding stage.

Table 3. Results of analysis of variances for S. arbuscula forage quality

\begin{tabular}{|c|c|c|c|c|c|c|c|c|c|}
\hline \multirow{2}{*}{ S.O.V } & \multirow{2}{*}{ df } & \multicolumn{7}{|c|}{ M.S } \\
\cline { 3 - 10 } & & DMD(\%) & $\mathrm{CP}(\%)$ & WSC(\%) & $\mathrm{CF}(\%)$ & $\mathrm{ADF}(\%)$ & $\mathrm{NDF}(\%)$ & $\mathrm{ASH}(\%)$ & $\mathrm{ME}(\mathrm{Mj} / \mathrm{kg})$ \\
\hline Treatment & 2 & $94.5^{* *}$ & $25.9^{* *}$ & $31.46^{* *}$ & $57.6^{* *}$ & $84.11^{* *}$ & $313.39^{* *}$ & $1.11^{* *}$ & $2.7^{* *}$ \\
\hline Error & 6 & 3.66 & 0.42 & 0.67 & 0.14 & 3.32 & 4.15 & 0.05 & 0.09 \\
\hline \multicolumn{2}{|c|}{$\mathrm{CV}(\%)$} & 3.72 & 5.81 & 4.31 & 0.95 & 4.39 & 6.49 & 4.48 & 4.58 \\
\hline
\end{tabular}

*** significant in level of $5 \%$

Table 4. Mean comparisons of forage quality traits in S. arbuscula

\begin{tabular}{|c|c|c|c|c|c|c|c|c|}
\hline Treatment & $\mathrm{DMD}(\%)$ & $\mathrm{CP}(\%)$ & $\mathrm{WSC}(\%)$ & $\mathrm{CF}(\%)$ & $\mathrm{ADF}(\%)$ & $\mathrm{NDF}(\%)$ & $\mathrm{ASH}(\%)$ & $\mathrm{ME}(\mathrm{Mj} / \mathrm{kg})$ \\
\hline $\begin{array}{c}\text { Vegetative } \\
\text { stage }\end{array}$ & $51.33 \mathrm{~b}$ & $14.6 \mathrm{a}$ & $22.24 \mathrm{a}$ & $34.84 \mathrm{c}$ & $41.25 \mathrm{~b}$ & $22.15 \mathrm{c}$ & $4.44 \mathrm{~b}$ & $6.76 \mathrm{~b}$ \\
\hline $\begin{array}{c}\text { Flowering } \\
\text { stage }\end{array}$ & $45.9 \mathrm{c}$ & $9.49 \mathrm{~b}$ & $15.76 \mathrm{c}$ & $43.12 \mathrm{a}$ & $46.94 \mathrm{a}$ & $42.37 \mathrm{a}$ & $5.53 \mathrm{a}$ & $5.81 \mathrm{c}$ \\
\hline Seeding stage & $57.12 \mathrm{a}$ & $9.53 \mathrm{~b}$ & $19.01 \mathrm{~b}$ & $41.47 \mathrm{~b}$ & $36.36 \mathrm{c}$ & $29.62 \mathrm{~b}$ & $5.57 \mathrm{a}$ & $7.71 \mathrm{a}$ \\
\hline
\end{tabular}

In each column, means with the similar letters are not significantly different at $5 \%$ level of probability 


\section{Discussion and conclusion}

$S$. arbuscula is one of the desert species in Iran, is established in the saline and gypsum soils with a sandy texture and can plays an effective role in forage production, soil conservation and prevention of wind erosion. This plant is reproduced by seeds. The roots of this plant are straight and deep and the rootlets are horizontal.

Evaluation of $S$. arbuscula forage quality at 3 phenological stages showed that crude protein percentage was decreased with progress of growth stages progress from $14.6 \%$ in vegetative stage to $9.49 \%$ during flowering stage and finally to $9.53 \%$ in seeding stage. A slight increase in protein percentage at the seeding stage is because of the addition of seeds to the collected samples. The result is consistent to the results reported by Arzani et al. (2014), Hosseini et al. (2014) and Abarsaji et al. (2008). Panahi et al. (2012) reported different protein contents for this species collected from Isfahan, Semnan and Markazi Provinces. So that the highest protein content was recorded at the seeding stage, the flowering stage and the vegetative stage in Markazi, Isfahan and Semnan provinces, respectively. However, according to Dianati Tilaki et al. (2011), the highest protein percentage of the plant in saline rangelands of Sabzevar was found to be at the vegetative stage followed by the flowering and seeding stages. Since the approximate critical level of protein to meet the daily requirement of an animal unit is around 7\% (Arzani et al., 2014), thus the plant is able to supply this amount of protein required by livestock in all of phenological stages.

The percentage of acid detergent fiber (ADF) ranges from $46.94 \%$ at flowering stage to $36.36 \%$ at the seeding stage. This amount is slightly lower than its critical level that is around $50 \%$ (Arzani et al., 2014) and does not reach to 50\% at any stage. According to the results of a research carried out by Dianati Tilaki et al. (2011), S. arbuscula had the highest percentage of $\mathrm{ADF}$ at the flowering stage in the saline rangelands of Sabzevar. Panahi et al. (2012) stated that the highest value of this parameter occurred at seeding stage in the rangelands of Isfahan province and no significant differences were found between Semnan and Markazi provinces for ADF. The metabolizable energy (ME) of the study plant was calculated to be 7.71, 6.76, and 5.81 at seeding, vegetative and flowering stages, respectively. The higher amount of this trait at seeding stage is due to the presence of plant seeds in the tested sample. Panahi et al. (2012) reported the highest amount of metabolizable energy for all three studied provinces at the flowering stage. However, according to Dianati Tilaki et al. (2011), the highest amount of metabolizable energy in the study plant was obtained at the vegetative stage. Considering the critical level of metabolizable energy $(8 \mathrm{MJ})$, the values of metabolizable energy recorded for this plant were below the critical level needed to meet the daily requirement of a livestock unit at all stages.

The highest percentage of CF, NDF, and ash with values of 37.12, 42.43 and 5.53 was recorded at the flowering stage. Panahi et al. (2012) showed that the samples collected from Semnan and Markazi Provinces had the highest percentage of CF and NDF at the vegetative stage and at the seeding stage in Isfahan province.

In general, it can be concluded that 3 phenological stages have a significant effect on the average of forage quality indices of $S$. arbuscula; and the vegetative growth stage was identified as the best grazing season in the rangelands with this vegetation type due to the high percentage of protein and soluble carbohydrates. Seeding and flowering stages are of the following priority, respectively. 


\section{REFERENCES}

[1] Abarsaji, Gh., Shahi, Gh., Pasandi, M. (2008): Determination of forage quality of Hedysarum coronarium at phenological different stages. - Pajouhesh and Sazandegi 78: 51-55.

[2] Abd El Aziz, D.M. (1982): A study of the nutritive value of some range plants in the North Western Coastal Desert. - Ph.D. Thesis, Faculty of Agriculture, Ain Shams University, Egypt.

[3] Abd El-Rahman, H.H. (1996): Utilization of desert range poor quality feeds by sheep and goats. - M.Sc. Thesis, Faculty of Agriculture, Cairo University, Cairo, Egypt.

[4] Abtahi, M., Darvish, M. (2016): Assessment of vegetation degradation in arid regions by FAO/UNEP (Case study: Kashan Sub basin). - International Journal of Advanced and Applied Sciences 3(7): 54-59.

[5] Aghakhani, H., Ghorbanli, M. (1993): A contribution to the halophytic vegetation and flora of Iran. In Lieth and A.Al Massom (eds): Towards the rational use of high salinity tolerant plants. - Springer Netherlands 1: 35-44.

[6] Amiri, B., Rasouli, B. (2011): Determination of forage quality of Sasola rigida and Atriplex leucoclada at phenological different stages. - The National Conference on agricultural management, Iran.

[7] Anon (2009): Introduction of salt-tolerant forage production systems to salt-affected lands in Sinai Peninsula in Egypt: a pilot demonstration project. - Final Report, DRC, Egypt-ICBA, UAE.

[8] AOAC (1990): Official method of analysis. (15th, edition). - Association of official analytical. Chemists, Washington, DC. USA.

[9] Arzani, H., Zohdi, M., Fish, E., Zahedi Amiri, G. H., Nikkhah, A., Wester, D. (2001): Phenological effects on forage quality of five grass species. - Journal of Range Management 57:624-629.

[10] Arzani, H., Tarnian, F., Motamedi, J., Khodagholi, M. (2014): Investigation on forage quality of range species in steppe rangelands of Maime, Isfahan. - Iranian Journal of Range and Desert Reseach 21(2): 198-207.

[11] Atiq-ur-Rehman (2002): Utilization of Atriplex as forage under grazing and cut and carry systems for small ruminants. - Proceedings of the International Symposium on Optimum Resources Utilization in Salt affected Ecosystems in Arid and Semi-arid Regions, Cairo, Egypt.

[12] Bakhshi Khaniki, Gh.R. (2006): Karyotype study of some species of the genus Salsola L. in Golestan province. - Pajouhesh and Sazandegi 72: 66-72.

[13] Buxton, D. R., Mertens, D. R., Fisher, D. S. (1996): Forage quality and ruminant utilisation. In Moser, L. E. et al. (Eds.). Cool-season Forage Grasses. ASA, CSSA, and SSSA, Madison, USA, pp. 229-266.

[14] Cavusoglu, K., Kilic, S., Kabar, K. (2007): Some morphological and anatomical observations during alleviation of salinity $(\mathrm{NaCl})$ stress on seed germination and seedling growth of barley by polyamines. - Acta Physiologiae Plantarum 29:551-557.

[15] Dianati Tilaki, Gh.A., Haidarian Aghakhani, M., Filehkesh, I., Naghipour Borj, A.A. (2011): Investigation on the effects of Phenological Stages on Forage Quality and Soluble Carbohydrates in Salsola arbuscula and Salsola richterispecies in Saline Rangelands of Sabzevar. - Iranian journal of Range and Desert Reseach 18(4): 652-661.

[16] EL-Bassiouny H. M. S., Bekheta M. A. (2007): Effect of Salt Stress on Relative Water Content, Lipid Peroxidation, Polyamines, Amino Acids and Ethylene of Two Wheat Cultivars. - Agriculture and Biologiacal Science 7:363-368.

[17] El Shaer, H.M., Ali, F.T., Nadia, Y.S., Morcos, S., Emam, S.S., Essawy, A.M. (2005): Seasonal changes of some halophytic shrubs and the effect of processing treatments on their utilization by sheep under desert conditions of Egypt. - Egyptian Journal Nutrition and Feeds 8: 417-431. 
[18] El Shaer, H.M., Zahran, M.A. (2002): Utilization of halophytes in Egypt: an overview. Proceedings of the International Conference on "Halophyte Utilization and Regional Sustainable Development of Agriculture", Huanghua, Shijiazhnag, China, pp. 20-26.

[19] Fahey, G. Jr. (1994): Forage Quality, Evaluation and Utilization. - ASA, CSSA, Madison, Wisconsin, USA.

[20] Gihad, E.A., El Shaer, H.M. (1994): Nutritive value of halophytes. - Squires, V.R., Ayoub, A.T. (Eds.), Halophytes as a Resource for Livestock and for Rehabilitation of Degraded Lands. Kluwer Academic Publishers, pp. 281-284.

[21] Glenn, E.P., Brown, J.J., Blumwald, E. (1999): Salt tolerance and crop potential of halophytes. - Critical Reviews in Plant Sciences 18: 227-255.

[22] Harrocks, D., Valentine, J. F. (1999): Harvested Forage. - San Diego, Academic Press, CA, $425 \mathrm{p}$.

[23] Hoffman, P. C., Lundberg, K. M., Bauman, L. M., Shaver, R. D. (2003): The effect of maturity on NDF digestibility. - Focus on Forage 5:1-3.

[24] Hosseini, S. A.,Mesdaghi, M. and Pambukhchyan, C. (2014): Study on the forage quality of five important grasses at different phenological stages in summer rangelands of Golestan province. - Iranian Journal of Range and Desert Reseach 21(2): 189-197.

[25] Jafari, A., Connolly, V., Frolich, A., Walsh. E. K. (2003): A note on estimation of quality in perennial ryegrass by Near Infrared Spectroscopy. - Irish journal of agricultural and food research 42: 293-299.

[26] Kilic, S., Cavusoglu, K., Kabar, K. (2007): Effects of 24-epibrassinolide on salinity stress induced inhibition of seed germination, seedling growth and leaf anatomy of barley. - Journal of Sciences 2:41-52.

[27] Le Houérou, H.N. (1993): Salt tolerant plants for the arid regions of the Mediterranean isoclimatic zone. - Leith, H., El-Masoom, A. (Eds.), Towards the Rational Use Of high Salinity-Tolerant Plants. Kluwer Academic Publications, Dordrecht, the Netherlands, pp. 405- 411.

[28] Le Houérou, H.N. (1994): Forage halophytes and salt-tolerant fodder crops in the Mediterranean Basin. - Squires, V.R., Ayoub, A.T. (Eds.), Halophytes as a Resource for Livestock and for Rehabilitation of Degraded Lands. Kluwer Academic Publishers, pp. 123-137.

[29] Mozaffarian, V.A. (1996): Dictionary of Iranian plant names. - Farhang Moaser publication, Tehran, Iran.

[30] Panahi, F., Assareh, M.H., Jafari, M. (2012): Phenological effects on Forage quality of Salsola arbuscula, Salsola orientalis and Salsola tomentosain in three habitats in the central part of Iran. - Middle-East Journal of Scientific Research 11 (6): 800-807.

[31] Squires, V.R., Ayoub, A.T. (1994): Halophytes as a Resource for Livestock and for Rehabilitation of Degraded Lands. - Kluwer Academic Publisher, Dordrecht Boston, London, $315 \mathrm{p}$.

[32] Stoddart, L. A., Cook, C. V. and Harris, L. E. (1975). Determining the digestibility and metabolizable energy of winter range plant by sheep. - Journal of Animal Science 11:578-590.

[33] Walters, R. J. K. (1984): D-Value: The significance of small differences on animal performance. - Proceeding of the 18th NIAB Crop Conference, Cambridge, UK, pp. 60-68.

[34] Zahran, M.A. (1986): Forage potentialities of Kochia indica and Kochia scoparia in arid lands with particular reference to Saudi Arabia. - Arab Gulf Journal of Scientific Research 4(1): 53-68.

[35] Zahran, M.A. (1993): Juncus and Kochia: fiber and fodder producing halophytes under salinity and aridity stresses. - Handbook of Plant and Crop Stress. Marcel Dakker, Inc., NY, pp. 505-530.

[36] Zahran, M.A., Bahira, K., Mohammed, Mashaly, I.A. (1999): Introduction of nonconventional livestock fodder under drought and salinity stress of arid lands. Proceedings of the Workshop on Livestock and Drought Policies for Coping with Changes, FAO/DRC, Cairo, Egypt, pp. 120-129. 